\title{
RETHINKING THE RAMIFICATIONS OF REASONABLENESS REVIEW: STARE DECISIS AND REASONABLENESS REVIEW ON QUESTIONS OF LAW
}

\begin{abstract}
MICHELLE BIDDULPH*
The recent fashion in the Canadian law of judicial review is to apply the reasonableness standard of review to virtually any decision rendered by an administrative decision-maker. Reasonableness review is a deferential standard of review that requires a court to ensure that the administrative decision falls within a range of reasonable outcomes that are defensible in light of the facts and law. When reasonableness review is applied to questions of law, the Supreme Court has occasionally ruled that the question admits of only one reasonable interpretation and has affirmed or quashed an administrative decision on that basis.

This article addresses the difficult question of whether a judicial decision affirming that a provision admits of only one reasonable interpretation is strictly binding on an administrative decision-maker interpreting that provision in the future. If reasonableness review is premised on deference, then deference ought to apply to an administrative decision-maker's interpretation of that question in the future, even if it differs from the court's interpretation. After situating this issue within the principled foundation of the Canadian law of judicial review, this article explores possible solutions to this problem, attempting to balance the need to protect the rule of law against the rationale for deference to administrative interpretations of law in the first place. It ultimately concludes by suggesting that, should Canadian courts continue to apply reasonableness review to virtually all questions of law, a uniquely administrative law approach to stare decisis will need to be developed in order to maintain a coherent and principled system of judicial review.
\end{abstract}

\section{TABLE OF CONTENTS}

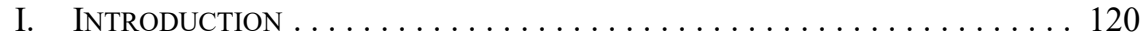

II. LEGISLATIVE INTENT, THE RULE OF LAW, AND REASONABLENESS REVIEW . . . . . . . . . . . . . . . . . 122

III. REASONABLENESS REVIEW ON QUESTIONS OF LAW . . . . . . . . . . . . . . . . . . . . 124

IV. Stare Decisis and Canadian Administrative LaW . . . . . . . . 126

A. Stare Decisis in the Common LaW . . . . . . . . . . . . 127

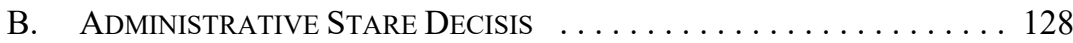

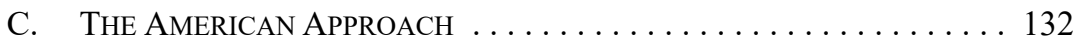

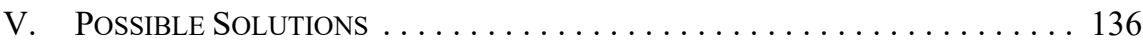

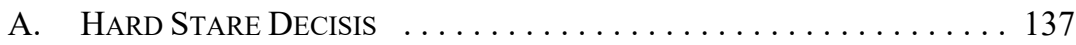

BA (Saskatchewan), JD (Saskatchewan), Associate Lawyer, Greenspan Humphrey Weinstein (Toronto). This article benefitted significantly from the brilliance of a number of different people. I would specifically like to thank William Lane, Terry Skolnik, Al-Amyn Sumar, Patrick Hartford, and Dwight Newman for commenting on various drafts of this article; as well as Edward Béchard-Torres and Olga Redko for continually strengthening and challenging my understanding of administrative law. I would also like to thank the two anonymous reviewers for their helpful input, as well as the editors of the Alberta Law Review for their hard work. Due to my clerkship at the Supreme Court of Canada in 2015 2016, my failure to discuss Supreme Court cases from that session is intentional. 
B. No Stare Decisis $\ldots \ldots \ldots \ldots \ldots \ldots \ldots \ldots \ldots \ldots \ldots \ldots \ldots \ldots$

C. Common Law Stare Decisis . . . . . . . . . . . . . . . . . . . . . . . 143

VI. CONCLUSION ................................ 147

\section{INTRODUCTION}

When it comes to judicial review of administrative action, the current fashion in Canadian administrative law is to review administrative decisions on a deferential reasonableness standard, giving "respectful attention" to the reasons that are offered or could be offered in support of an administrative decision ${ }^{1}$ to ultimately determine whether that decision "falls within a range of possible, acceptable outcomes which are defensible in respect of the facts and law." 2 This deferential approach has dominated the Supreme Court's post-Dunsmuir jurisprudence, encompassing questions of law, ${ }^{3}$ fact, ${ }^{4}$ policy, ${ }^{5}$ and everything in between, marginalizing the role and utility of the correctness standard of review in administrative law to the point of virtual irrelevance. ${ }^{6}$

When pure questions of law are reviewed on the reasonableness standard, the Supreme Court has (implicitly) ${ }^{7}$ directed that a reviewing court must adopt one of two approaches: it must either affirm that the question of law is open to multiple reasonable interpretations ${ }^{8}$ and assess whether the tribunal's interpretation is one of those reasonable interpretations, or it must conclude that, in light of the legislative scheme, the question of law "admits of only one reasonable interpretation." In the latter situation, if a court finds that the legislative scheme is open to only one reasonable interpretation, the administrative decision will be quashed if it does not adopt this singular reasonable interpretation. ${ }^{10}$

For the courts, finding that one reasonable interpretation and either affirming or quashing the administrative decision is the end of the story. But for that administrative decision-maker, the story is just beginning: faced with a judicial decision affirming that there is only one reasonable answer to a question of law that it encounters in the exercise of its statutory powers, is that administrative decision-maker necessarily bound by the judicial

Dunsmuir v New Brunswick, 2008 SCC 9 [Dunsmuir], citing David Dyzenhaus, "The Politics of Deference: Judicial Review and Democracy" in Michael Taggart, ed, The Province of Administrative Law (Oxford: Hartford, 1997) 279 at 286.

Dunsmuir, ibid at para 47.

See e.g. McLean v British Columbia (Securities Commission), 2013 SCC 67.

Dunsmuir, supra note 1 at para 53.

See e.g. Agraira v Canada (Public Safety and Emergency Preparedness), 2013 SCC 36 [Agraira], dealing, in part, with review of the Minister's policy decision that individuals with sustained contact with terrorist organizations were inadmissible to Canada.

6 See e.g. Lauren J Wihak, "Wither the Correctness Standard of Review? Dunsmuir, Six Years Later" (2014) 27:2 Can J Admin L \& Prac 173.

While this has not appeared as an explicit direction in any administrative law jurisprudence, it does appear to implicitly describe the standard approach taken to reasonableness review on pure questions of law. Some academic literature have heavily criticized this move toward a preliminary assessment of the number of reasonable interpretations possible under a statutory provision: see e.g. Frank AV Falzon, "Statutory Interpretation, Deference and the Ambiguous Concept of "Ambiguity" on Judicial Review" (2016) 29:2 Can J Admin L \& Prac 135 (arguing that any implicit "preliminary inquiry" into whether a statutory provision is ambiguous or not is not a welcome development in Canadian administrative law, as it is "unnecessary, and risks being conclusory" at 137).

Dunsmuir, supra note 1 at para 47.

Wilson v British Columbia (Superintendent of Motor Vehicles), 2015 SCC 47 at para 25 [Wilson].

See e.g. Canada (Canadian Human Rights Commission) v Canada (Attorney General), 2011 SCC 53 at para 64 [Mowat]. 
interpretation? In what situations is it free to depart from that interpretation? And how should courts review an administrative decision that chooses to depart from the one reasonable interpretation that was affirmed by the courts? These are difficult questions that have rarely been addressed in Canadian jurisprudence or academic literature. ${ }^{11}$

If one accepts the Supreme Court's description of reasonableness review, one must accept that reasonableness review always requires a court to grant deference to the administrative decision-maker. No deference, no reasonableness review - and vice versa. ${ }^{12}$ A judicial decision that affirms (or decides) that there is only one reasonable interpretation of a statutory provision available is still ostensibly reaching that conclusion through appropriate deference to the administrative decision-maker. But what does deferential reasonableness review mean when an administrative decision-maker renders a changed interpretation of a statutory provision? Must a court bind an administrative decision-maker to an earlier judicial interpretation, or is it possible for the administrative decision-maker to adopt a new interpretation in the face of a "one reasonable interpretation" ruling?

This article proposes three possible solutions to this stare decisis problem, though these proposed solutions are certainly not exhaustive of the possibilities for addressing this issue. These proposed solutions are based on the premise that courts have applied and will continue to apply reasonableness review to determine that a statute admits of only one reasonable interpretation. It does not question or address the wisdom of adopting a "one reasonable interpretation" approach to reasonableness review on certain questions of law - many others have done so, ${ }^{13}$ yet those criticisms seem to have been met with little reception from the Supreme Court. ${ }^{14}$ This article instead takes a different tack: if one accepts the Supreme Court's description of reasonableness review on questions of law at its word, what happens next?

The first potential solution is to adopt what American courts have endorsed and hold that where an authoritative interpretation of a statutory provision is pronounced by a court on judicial review of an administrative decision, that interpretation is binding on administrative

11 One exception is in the work of Paul Daly, "The Principle of Stare Decisis in Canadian Administrative Law" (2015) 49:3 RJTUM 757 [Daly, "Principle of Stare Decisis"]. Daly's thesis will be discussed further in Part IV.B, below.

12 An explicitly non-deferential standard of review, is, instead, correctness review: see Dunsmuir, supra note 1 at para 50 .

13 See e.g. Daly, "Principle of Stare Decisis," supra note 11 at 770-71; Falzon, supra note 7 at 149-56; Matthew Lewans, "Renovating Judicial Review" (2017) 68 UNBLJ 109 at 133-34 (criticizing the "one reasonable interpretation" approach to reasonableness review, at least as it has been applied in recent Supreme Court decisions); Paul Daly, "The Signal and the Noise in Administrative Law" (2017) 68 UNBLJ 68 at 71 (identifying the tension between principles of judicial review and the Supreme Court's overarching guidance mandate when it comes to reasonableness review on questions of law); Paul Daly, "Struggling Towards Coherence in Canadian Administrative Law? Recent Cases on Standard of Review and Reasonableness" (2016) 62:2 McGill LJ 527 at 559-63; David Mullan, "The True Legacy of Dunsmuir - Disguised Correctness Review?" (15 February 2018), Double Aspect (blog), online: $<$ https://doubleaspect.blog/2018/02/15/the-true-legacy-of-dunsmuir-\%E2\%80\%95-disguisedcorrectness-review/>; Martin Olszynski, "Moving Dunsmuir Past Dunsmuir" (21 February 2018), Double Aspect (blog), online: <https://doubleaspect.blog/2018/02/21/moving-dunsmuir-past-duns muir/>; Lauren J Wihak, "Correctness Review” (20 February 2018), Administrative Law Matters (blog), online: <www.administrativelawmatters.com/blog/2018/02/20/correctness-review-lauren-j-wihak/>; The Honourable Joseph T Robertson, "Dunsmuir's Demise and the Rise of Disguised Correctness Review" (15 February 2018), Administrative Law Matters (blog), online: <www.administrativelawmatters.com/ $\mathrm{b} \log / 2018 / 02 / 15 /$ dunsmuirs-demise-the-rise-of-disguised-correctness-review-the-hon-joseph-trobertson/>.

14 See e.g. Groia v Law Society of Upper Canada, 2018 SCC 27 at para 125. 
decision-makers and they are not free to depart from it. ${ }^{15}$ Another solution is to apply horizontal stare decisis between courts and administrative tribunals, allowing the administrative decision-maker to depart from what the judiciary deemed to be the one reasonable interpretation where the decision-maker, exercising its expertise and policymaking function, deems it prudent to do so. ${ }^{16}$ The third would be to affirm that administrative decision-makers are, generally, bound by stare decisis when a court declares one interpretation of a statute to be the only reasonable interpretation, but that the common law exceptions to stare decisis are available, ${ }^{17}$ and, where those exceptions apply, the decisionmaker is free to depart from the court's interpretation. ${ }^{18}$ These exceptions could be appropriately modified for the practice of judicial review, defining their contours in a manner that would respect both the deferential mandate of reasonableness review and the courts' constitutional role in upholding the rule of law.

This article will begin by outlining the general principles behind the Canadian law of judicial review, pointing to the confluence and divergence of constitutional principles as they apply to the specific question of statutes that purportedly admit of only one reasonable interpretation in Canadian administrative law. Part III will outline the Supreme Court's direction on reasonableness review on questions of law, especially those that admit of only one reasonable answer. Part IV will then turn to the specific issue of stare decisis in administrative law, outlining the scant attention that has been paid to this issue in Canada as well as the wealth of jurisprudence and related academic literature on this issue in the United States. Part V will outline various methods that Canadian courts could choose to resolve this issue, commenting on each method's strengths and weaknesses. Part VI will offer final conclusory thoughts and suggestions for the way forward, ultimately suggesting that the development of a uniquely administrative law approach to stare decisis between courts and tribunals is the best solution to the stare decisis problem if reasonableness review on questions of law is here to stay.

\section{LEgislative InTENT, THE RULE OF LAW, AND REASONABLENESS REVIEW}

The Canadian law of judicial review is based on two core principles: the rule of law and the principle of democracy, often framed as the principle of legislative intent. ${ }^{19}$ Administrative actors are creatures of statute, but exercise delegated executive power in fulfilling their statutory mandates. Administrative actors often exercise judicial functions as well, resolving disputes and issuing binding rulings in non-judicial administrative forums.

15

Maislin Industries, US v Primary Steel, 497 US 116(1990) (“'[o]nce we have determined a statute’s clear meaning, we adhere to that determination under the doctrine of stare decisis, and we judge an agency's later interpretation of the statute against our prior determination of the statute's meaning" at 131).

16 See The Honorable Antonin Scalia, "Judicial Deference to Administrative Interpretations of Law" [1989] 3 Duke LJ 511 at 517-19.

17 As they currently exist in Canadian jurisprudence. It is beyond the scope of this article to dig into the theoretical foundations of the common law exceptions to stare decisis to explore their application in administrative law - such a task is better suited to a graduate thesis rather than a practitioner's article. Instead, as it does with reasonableness review, this article accepts the Supreme Court's description of the exceptions to stare decisis at its word and explores how those principles can be applied in administrative law in a practical manner.

Most recently summarized in Canada (Attorney General) v Bedford, 2013 SCC 72 at para 42 [Bedford]; Carter v Canada (Attorney General), 2015 SCC 5 at para 44.

Dunsmuir, supra note 1 at para 27. 
The courts police administrative action, ensuring that administrative decisions respect principles of procedural fairness and that administrative actors stay within the bounds of their delegated legislative authority.

The deference revolution in the law of judicial review has been one prompted by concern for legislative intent: where the legislature has expressly chosen to remove a legal issue from the courts and grant it to administrative actors to administer and resolve, courts ought not to undermine that clear choice by substituting their views for the expert decisions of administrative actors. ${ }^{20}$ In other words, the legislature chose to create expert decision-makers and imbue them with the power to resolve disputes within certain jurisdictional bounds. When it comes to issues within those bounds, courts are generalists; administrative actors are specialists. Generalist courts ought to defer to the decisions of administrative decisionmakers on those specialized issues. ${ }^{21}$

Of course, the principle of legislative intent, acting alone, would theoretically mandate unlimited deference to administrative actors. After all, if the legislature chose to remove a particular decision from the courts, why would the courts ever be justified in intervening with respect to that issue? Any intervention that could substitute the court's view for the tribunal's view would offend the principle of legislative intent. This is where the rule of law comes in: the Supreme Court has determined that the legislature cannot deprive superior courts of the power to judicially review administrative decisions altogether, as to do so would violate rule of law considerations and section 96 of the Constitution Act, $1867 .{ }^{22}$ Deference based on legislative intent therefore has a limit.

Respect for legislative intent requires a court to respect the legislature's choice to grant the power to make a particular decision to an administrative decision-maker, rather than to the courts. But respect for legislative intent also requires courts to ensure administrative decision-makers are abiding by their legislative grants of authority, as neither courts nor tribunals may act in a manner that is contrary to legislative intent. In the current understanding of judicial review, this means that courts must ensure that administrative decisions are reasonable. When it comes to judicial review on questions of law, courts must ensure that administrative decision-makers are respecting legislative intent and are not rendering interpretations of legal provisions that are contrary to the plain or ordinary meaning of those provisions, or contrary to what the legislature intended in enacting that provision.

The conflict and concert between these two foundational pillars of judicial review creates reasonableness review. Legislative intent drives the deferential underpinnings of reasonableness review - courts defer to administrative decisions because the legislature

20 See e.g. UES, Local 298 v Bibeault, [1988] 2 SCR 1048 at 1089; Dr Q v College of Physicians and Surgeons of British Columbia, 2003 SCC 19 at para 21. See also Cass R Sunstein \& Adrian Vermuele, "The Unbearable Rightness of Auer" (2017) 84:1 U Chicago L Rev 297 (providing a sustained justification for judicial deference to administrative interpretations of law).

$21 \quad$ See e.g. Mouvement laïque québécois v Saguenay (City), 2015 SCC 16 at para 172; Moreau-Bérubé v New Brunswick (Judicial Council), 2002 SCC 11 at para 45; Newfoundland and Labrador Nurses' Union $v$ Newfoundland and Labrador (Treasury Board), 2011 SCC 62 at para 13.

22 (UK), 30 \& 31 Vict, c 3, reprinted in RSC 1985, Appendix II, No 5. See Crevier v Quebec (AG), [1981] 2 SCR 220 [Crevier]. 
chose to entrust the tribunal with the power to make that decision. The legislature created specialized tribunals, and those specialized tribunals develop a measure of institutional and specific expertise that courts cannot match. Principled and policy reasons therefore mandate deference from generalist courts to those specialist tribunals. But the rule of law acts as a bulwark against abdication of the judicial role, ensuring that courts do not blindly defer simply because legislative intent mandates deference. The rule of law permits courts to determine the limits of reasonable interpretations of statutory schemes and to ensure that administrative decisions reflect appropriate transparency, intelligibility, and justification in the reasoning process. $^{23}$

\section{Reasonableness Review on Questions of LAW}

While the above discussion sets out the theoretical foundation for reasonableness review, these abstract principles have little to say about how courts should actually conduct reasonableness review on pure questions of law. Reasonableness review, as the oft-quoted paragraph of Dunsmuir says, is premised on the understanding that certain questions do not lend themselves to one particular result:

\footnotetext{
Reasonableness is a deferential standard animated by the principle that underlies the development of the two previous standards of reasonableness: certain questions that come before administrative tribunals do not lend themselves to one specific, particular result. Instead, they may give rise to a number of possible, reasonable conclusions. Tribunals have a margin of appreciation within the range of acceptable and rational solutions. A court conducting a review for reasonableness inquires into the qualities that make a decision reasonable, referring both to the process of articulating the reasons and to outcomes. In judicial review, reasonableness is concerned mostly with the existence of justification, transparency and intelligibility within the decisionmaking process. But it is also concerned with whether the decision falls within a range of possible, acceptable outcomes which are defensible in respect of the facts and law. ${ }^{24}$
}

However, when it comes to certain questions of statutory interpretation, the Supreme Court has affirmed that reasonableness review is the appropriate standard of review, but that, despite this deferential standard, the question before the administrative tribunal admits of only one permissible - that is, reasonable — interpretation. If the administrative decisionmaker's interpretation differs from the one reasonable interpretation, it is necessarily unreasonable. While there are many cases that serve as useful examples of this, I will limit myself to one: Canada (Canadian Human Rights Commission) v. Canada (Attorney General) (better known as Mowat). ${ }^{25}$

23 Dunsmuir, supra note 1 at para 47. This is, of course, an abstract and bird's-eye overview of the foundational principles of judicial review. It does not capture all of the principled nuances that justify deference and mandate intervention. However, it is intended to appropriately lay the foundation for assessing the stare decisis issue at the heart of this article.

24 Ibid.

25 Supra note 10. Another good example is Wilson, supra note 9 at para 6, dealing with the "only reasonable" interpretation of a provision of British Columbia's Motor Vehicle Act, RSBC 1996, c 318. Similar approaches were also taken in Wilson $v$ Atomic Energy of Canada Ltd, 2016 SCC 29 (with the majority, led by Justice Abella, implying that there was only one reasonable interpretation of the impugned provisions, while the dissent, applying correctness review, concluded that the exact opposite interpretation was the correct one); and Vavilov $v$ Canada (Citizenship and Immigration), 2017 FCA 132. 
Mowat centered on the question of whether section 53(2) of the Canadian Human Rights $A c t^{26}$ permitted the Canadian Human Rights Tribunal to award legal costs to a successful complainant. The Tribunal concluded that it had such authority, stating that a victory before the Tribunal would be "pyrrhic" if the successful complainant could not recoup some of his or her legal costs. ${ }^{27}$ The Federal Court of Appeal disagreed, holding — on a correctness standard of review - that the Tribunal did not have the authority to award legal costs because Parliament specifically chose not to grant that authority to the Tribunal. ${ }^{28}$ The Supreme Court also disagreed, but utilized the reasonableness standard of review to conclude that the only reasonable interpretation of section 53(2) of the Canadian Human Rights Act was that the Tribunal was not empowered to award legal costs.

Justices LeBel and Cromwell wrote the unanimous opinion of the Supreme Court. After concluding that reasonableness was the applicable standard of review, they found that an interpretation that would permit the Tribunal to award legal costs to a successful complainant was not a reasonable interpretation. This question, they said, was "one of statutory interpretation and the object is to seek the intent of Parliament by reading the words of the provision in their entire context and according to their grammatical and ordinary sense," harmoniously with the scheme of the Act as a whole. ${ }^{29}$ They applied a wholesale statutory interpretation analysis, assessing the meaning of the text of the provision, ${ }^{30}$ the legislative history of the provision, ${ }^{31}$ the Human Rights Commission's understanding of the meaning of the provision, ${ }^{32}$ comparable provisions in provincial and territorial legislation, ${ }^{33}$ and the purpose of the legislation ${ }^{34}$ to reach the conclusion that "the text, context and purpose of the legislation clearly show that there is no authority in the Tribunal to award legal costs and that there is no other reasonable interpretation of the relevant provisions." 35 The Tribunal's decision on costs was accordingly quashed. ${ }^{36}$

This case serves as an example of how courts may conclude that a statutory provision admits of only one reasonable interpretation and either affirm or quash an administrative decision on that basis. Of course, it is not a perfect example of the application of reasonableness review, as the reasoning is susceptible to the criticism that the Supreme Court improperly applied reasonableness review and, in fact, engaged in disguised correctness review. ${ }^{37}$ But whether these sorts of decisions are impugned or discarded as inappropriate applications of reasonableness review or not, the fact remains that the Supreme Court has concluded — on the presumably deferential reasonableness standard - that only one reasonable interpretation of the statutory provision at issue was available.

RSC 1985, c H-6.

Mowat $v$ Canadian Armed Forces, 2006 CHRT 49 at para 29.

Canada (Attorney General) v Mowat, 2009 FCA 309.

Mowat, supra note 10 at para 33.

Ibid at paras $35-41$.

Ibid at paras 43-52.

Ibid at paras 53-56.

Ibid at paras 57-60.

Ibid at paras 61-64.

Ibid at para 64

Ibid.

See e.g. David Mullan, "Unresolved Issues on Standard of Review in Canadian Judicial Review of Administrative Action - the Top Fifteen!" (2013) 42:1-2 Adv Q 1 at 76. 
This is not necessarily an incorrect or illogical reasoning process. As Justice Stratas has explained in the Federal Court of Appeal, given the "text, context and purpose of the statute," the range of reasonable outcomes open to an administrative decision-maker when deciding a pure question of law may very well be limited to one. ${ }^{38}$ This is not an inappropriate application of reasonableness review, but, rather, a recognition of the obvious fact that the administrative decision-maker is as much bound by the legislature's intent as the court is. If the principles of statutory interpretation lead to the conclusion that the legislature only intended one meaning, then, reasonableness review or not, it is that meaning that must prevail. $^{39}$

When it comes to certain questions of statutory interpretation, the deferential underpinnings of reasonableness review tend to fade into the background, eclipsed by the importance of legislative intent. There is no room to allow the administrative decision-maker to choose between multiple reasonable outcomes because such a choice cannot exist: there is only one possible outcome, that which is dictated by the clear intention of the legislature. ${ }^{40}$ Assuming for the sake of this article that the courts bear the ultimate responsibility for divining and implementing the legislature's clear intention on some matters of statutory interpretation $^{41}$ — and either affirming or quashing administrative decisions on this basis we must address the implications of this: what happens after a court decides that only one interpretation is reasonable? Is that conclusion binding on administrative decision-makers?

\section{Stare Decisis and Canadian Administrative LaW}

The question of whether and when a judicial decision is binding on an administrative actor raises the issue of stare decisis in administrative law. The question of how stare decisis as a common law principle ought to apply in administrative law is one that has received scant judicial or academic attention in Canada. I am referring here only to vertical stare decisis, that is, stare decisis between courts and tribunals. It is well settled that horizontal stare decisis applies between tribunals themselves. ${ }^{42}$ The same can be said of vertical stare decisis between tribunals and appeal tribunals, as both exist within the same specialized structure

Canadian Human Rights Commission v Canada (Attorney General), 2013 FCA 75 at para 14. See also Wilson $v$ Atomic Energy of Canada Limited, 2015 FCA 17 at paras 59-62, rev'd supra note 25 (reversed, but still a useful explanation of how certain questions can limit themselves to only one reasonable outcome).

39 Of course, this presumes that any method of statutory interpretation can yield one clear answer. This proposition is certainly debatable: see e.g. Falzon, supra note 7 at $145-49$; Brian G Slocum, "The Importance of Being Ambiguous: Substantive Canons, Stare Decisis, and the Central Role of Ambiguity Determinations in the Administrative State" (2010) 69:4 Md L Rev 791.

40 The Supreme Court has continued to insist that courts are and ought to be engaging in reasonableness review when they make this determination: see e.g. Canada (Canadian Human Rights Commission) $v$ Canada (Attorney General), 2018 SCC 31 at para 40; Wilson, supra note 9 at para 25. One might (quite presciently) observe that this is not deferential review, and it therefore ought not to be labelled as reasonableness review. Again, the purpose of this article is not to question the wisdom or logical consistency of the Supreme Court's choice of label. Its purpose is only to explore the ramifications of that insistence for future rulings on that same question.

41 The way that reasonableness review on these clear types of questions has been conducted in Canada bears remarkable similarity to the theory behind the two-step Chevron doctrine in the United States. This will be discussed further in Part IV, below. For now, however, it is worth noting that Canadian courts and academics have not engaged in the same sort of spirited debate as the Americans have about when and in what circumstances a statutory provision is "clear" enough that only one reasonable interpretation - that which is endorsed by the reviewing court — is possible. If reasonableness review is to continue down the same path it has headed since Dunsmuir, this is a question that will eventually need to be answered for any sort of clarity or predictability in the reasonableness analysis to be possible. See e.g. IWA $v$ Consolidated-Bathurst Packaging Ltd, [1990] 1 SCR 282 [IWA]. 
created by the legislature for the purpose of regulating a particular issue. The legislature presumably intended for the appeal tribunal's rulings on questions of law to bind the lower tribunal, as otherwise there would be little point in creating an appeal tribunal. The only concern of this article is vertical stare decisis between the administrative and judicial systems: when is an administrative decision-maker bound, as a matter of stare decisis, by the decision of a court?

\section{A. Stare Decisis in the Common LaW}

The concept of vertical stare decisis is fundamental to the development and operation of the common law. It is, at heart, a practical principle: once a point of law is decided by a higher court, it cannot be overturned by a lower court. This is justified based on the need for certainty, consistency, and predictability in the law. ${ }^{43}$ As Justice Laskin of the Ontario Court of Appeal once put it, "[p] eople should be able to know the law so that they can conduct themselves in accordance with it." 44

The principle of vertical stare decisis is premised on a concern for the rule of law. The rule of law is a foundational, though remarkably, undefined principle of Canadian constitutional law. ${ }^{45}$ Peter Hogg and Cara Zwibel offered one account of the meaning of this principle, based on their review of the Supreme Court of Canada's case law:

[W] propose three elements to the rule of law: (1) a body of laws that are publicly available, generally obeyed, and generally enforced; (2) the subjection of government to those laws (constitutionalism); and (3) an independent judiciary and legal profession to resolve disputes about those laws. ${ }^{46}$

Vertical stare decisis serves the first of those elements. It is a common law rule that gives legal effect to common law judgments. By promoting intelligibility, consistency, and predictability in the common law, vertical stare decisis helps shape what would otherwise be a peripatetic body of judicial decisions into an orderly system of law. As Justice Brown (as he then was) explained in R. v. Caswell (JA):

As a practical matter, the legal system cannot sustain the uncertainty and expense that would flow from reconsidering every appellate decision ever pronounced on section 8 and section 10 of the Charter. More fundamentally, accessibility of the law — which is a core principle of the rule of law ... - requires that the law be intelligible, clear and predictable, and subject to orderly development in incremental steps.... Constitutional legal order itself presupposes the creation and maintenance of positive laws. Since the enactment of the Charter, courts in Canada have carefully sought, decision by decision, to balance the relationship between Charter rights and the Criminal Code. The public interest is not served by upsetting that balance whenever it is asserted that "it's different now.",47

See e.g. David Polowin Real Estate Ltd v Dominion of Canada General Insurance Co (2005), 76 OR (3d) 161 (CA) at para 119 [Polowin Real Estate].

Ibid.

As Justice Strayer of the Federal Court of Appeal once observed, "[a]dvocates tend to read into the principle of the rule of law anything which supports their particular view of what the law should be" (Singh v Canada (Attorney General) (CA), [2000] 3 FC 185 (CA) at para 33, cited in British Columbia $v$ Imperial Tobacco Canada Ltd, 2005 SCC 49 at para 62).

Peter W Hogg \& Cara F Zwibel, "The Rule of Law in the Supreme Court of Canada" (2005) 55:3 UTLJ 715 at 718 .

2015 ABCA 97 at para 38 [citations omitted] [Caswell]. 
Horizontal stare decisis sits on slightly different footing. Vertical stare decisis applies between appellate courts and lower courts. The rule in an appellate decision is binding on a lower court, absent certain narrow exceptions. Horizontal stare decisis applies within the same level of court. No judge is bound by a decision of that judge's same level of court, and no appellate court is bound by its previous decisions. However, as Justice Binnie explained in R. v. Henry, the Supreme Court's practice "is against departing from its precedents unless there are compelling reasons to do so."48 This practice promotes the same values of consistency, predictability, and stability in the law that underlie the principle of vertical stare decisis. Both types of stare decisis exist to serve rule of law values in the common law system.

\section{B. Administrative Stare Decisis}

Stare decisis in administrative law is less defined than it is in the ordinary common law system. While it is well-established that horizontal stare decisis applies between decisions of tribunals, ${ }^{49}$ there is no such judicial, administrative, or academic consensus on how vertical stare decisis should apply between courts and administrative decision-makers. This section will therefore outline the scant consideration that the issue has received in decisions of courts and tribunals, as well as Canadian academic thought on this issue.

There is only one Supreme Court decision that directly addresses this issue, though not precisely in the reasonableness review context: Régie des rentes du Québec v. Canada Bread Company Ltd. ${ }^{50}$ In that case, the Supreme Court considered the binding effect of a Court of Appeal judgment on an administrative tribunal in a complex pension benefits case. The case involved a pension fund which was paid into by the respondents. The respondents were employers in Quebec that chose to close down several of their divisions. The closures created a significant shortfall in the fund. Under the rules of the fund, employee benefits could be reduced if employer contributions were insufficient to cover the fund's shortfall. ${ }^{51}$ The Régie, the administrator of the Supplemental Pension Plans Act in Quebec, ${ }^{52}$ appointed a review committee to review the rules of the fund, which ultimately concluded that the rules of the fund were inconsistent with the SPPA and were of no force and effect. ${ }^{53}$ The matter made its way to the Quebec Court of Appeal, which concluded that the rules of the fund were not inconsistent with the SPPA and that they should be given full effect. The matter was remitted to the Régie to review its initial decision in light of the Court of Appeal's ruling. ${ }^{54}$

Following the Court of Appeal's decision, the Quebec National Assembly introduced a bill to invalidate the rules of the fund and counter the effects of the Court of Appeal's judgment. This bill was declaratory in nature, but it ultimately passed. Following the enactment of the bill, the Régie refused to follow the Court of Appeal's decision and refused to apply the rules of the fund in a manner that would reduce the benefits payable to the plan's members and beneficiaries, thereby confirming the Régie's initial decision. The question that

2005 SCC 76 at para 44.

IWA, supra note 42.

2013 SCC 46 [Canada Bread Company].

Ibid at paras 5-8

RSQ c R-15.1 [SPPA].

Canada Bread Company, supra note 50 at para 10.

Ibid at para 11 . 
the Supreme Court had to decide was whether the Régie was entitled to disregard the Court of Appeal's decision in light of the subsequent declaratory legislation enacted by the National Assembly. ${ }^{55}$

After concluding that the matter was not res judicata as a result of the Court of Appeal's first decision, Justice Wagner (as he then was), writing for the majority, turned to the issue of stare decisis. He stated that "[w]here an administrative decision-maker has a duty to follow the directions of a reviewing court, it is on the basis of stare decisis." ${ }^{56}$ However, stare decisis is premised on the reviewing court's decision being good law. Where the reviewing court's decision is overturned by a higher court or ousted by the legislature, Justice Wagner concluded that the administrative decision-maker is no longer obligated to follow the reviewing court's decision. ${ }^{57}$

Canada Bread Company therefore stands for the proposition that, where there is a change in law between the time a matter is remitted to an administrative decision-maker and the time the administrative decision-maker renders its second decision, the decision-maker is no longer bound by the decision of the higher court and instead must give effect to the changed law. A similar conclusion was reached by the Federal Court of Appeal in Canada (Commissioner of Competition) v. Superior Propane Inc (C.A.). ${ }^{58}$ In that case, the Federal Court of Appeal had remitted a matter to the Competition Tribunal with directions after deciding that the Competition Tribunal had misinterpreted a provision of the Competition Act. ${ }^{59}$ The Competition Tribunal followed the Court's directions but reached the same result, and the matter found its way to the Federal Court of Appeal again. In concluding that the appeal must be dismissed, Justice Rothstein (as he then was) made some general comments on the application of stare decisis between courts and administrative tribunals:

The principle of stare decisis is, of course, well known to lawyers and judges. Lower courts must follow the law as interpreted by a higher co-ordinate court. They cannot refuse to follow it ....This principle applies equally to tribunals having to follow the directions of a higher court as in this case. On redetermination, the duty of a tribunal is to follow the directions of the reviewing court. ${ }^{60}$

Both Canada Bread Company and Superior Propane considered the issue of administrative stare decisis in the context of a direct remission by a superior court to a tribunal to reconsider the same case in light of the superior court's decision. Neither considered the issue of stare decisis when an administrative decision-maker chooses to depart from a superior court precedent in an unrelated case, that is, where the matter has not been remitted to the administrative decision-maker.

There are several pre-Dunsmuir decisions that have considered this issue along with several post-Dunsmuir decisions, though no clear resolution to the stare decisis issue can be

Ibid at paras $14-16$.

Ibid at para 46.

Ibid at para 47. While there was a dissent in the case, the dissent was primarily focused on the doctrine of res judicata. This doctrine, while related to stare decisis, is distinct. It is not engaged by the stare decisis problem that this article addresses.

2003 FCA 53 [Superior Propane].

RSC 1985, c C-34

Superior Propane, supra note 58 at para 54 [citations omitted]. 
discerned from them. ${ }^{61}$ In Re Frontenac, Lennox and Addington Roman Catholic Separate School Board and Ontario English Catholic Teachers' Association ${ }^{62}$ a Board of Arbitration interpreted a provision of the Anti-Inflation $A c t^{63}$ in a manner that conflicted with an earlier Federal Court of Appeal decision. On judicial review for jurisdictional error, the Divisional Court concluded that the Board of Arbitration had exceeded its jurisdiction by failing to follow the Federal Court of Appeal's decision:

In our opinion, the decision of the Federal Court of Appeal ruling on a federal statute was binding on and ought to have been recognized by the board of arbitration. Therefore, the discretion of the board of arbitration not to report the increment in the face of this decision was, in our view, an error in law. ${ }^{64}$

Similarly, in Re Niagara Parks Commission, ${ }^{65}$ a 1999 decision of the Ontario Information and Privacy Commissioner, the Commissioner considered the binding effect of an Ontario Divisional Court decision interpreting a provision of the Commissioner's home statute dealing with denial of access to records based on invasion of privacy concerns. The Commissioner invited submissions from the Attorney General and other interested parties on the question of whether the Commissioner was entitled to depart from the Divisional

61 There are numerous decisions of boards and tribunals that consider the issue in passing or without any detailed discussion. This includes: Simard v Nipissing Condominium Corporation No 4, 2011 HRTO 1554 (CanLII) (implying that the common law exceptions to stare decisis would apply to an administrative tribunal). However, it was based on an Ontario Court of Appeal decision that was decided on the correctness standard (Nipissing Condominium Corp No 4 v Kilfoyl, 2010 ONCA 217). See also Fasulo v Canada (Minister of Public Safety and Emergency Preparedness), 2016 CanLII 84665 (Immigration and Refugee Board of Canada) [Fasulo] (simply stating that the Immigration Appeal Division was bound by a decision of the Federal Court of Appeal); Gomes v Canada (Minister of Citizenship and Immigration), 2004 CanLII 56710 (Immigration and Refugee Board of Canada) (reaching a similar conclusion as the Immigration Appeal Board in Fasulo, ibid); Nichol v Municipal Property Assessment Corp, Region No 03 (2017), 92 OMBR 459 (Ontario Assessment Review Board). While framing the decision as a question of stare decisis, the decision actually dealt more with the precedential effect of a prior judicial determination of a factual issue involving the same parties. This is more a question of issue estoppel than stare decisis; Global Edmonton $v$ Unifor Local M-1, 2015 CanLII 72296 (Alberta Grievance Arbritration Awards) (finding that a 1972 judicial decision was no longer binding as a matter of stare decisis, but implying that, were the Arbitrator to adopt an interpretation that a court had found to be unreasonable, the Arbitrator would be bound to refrain from adopting that interpretation in the future); $8909 v$ Registrar of Alcohol and Gaming, 2015 CanLII 26067 (Ontario License Appeal Tribunal) (simply stating that the Tribunal was bound as a matter of stare decisis to follow a decision of the Divisional Court on the availability of the defence of due diligence); Re WCAT-2006-02894, 2006 CanLII 89376 (BC Workers' Compensation Appeal Tribunal) (taking the opposite approach and concluding that the Tribunal was not bound by judicial interpretation of provisions of the Workers Compensation Act, RSBC 1996, c 492, though this conclusion was based on a provision in its enabling statute expressly stating that the Tribunal was not bound by legal precedent); Lionel Veilleux Ltd v Clubley, 1987 CanLII 2090 (Ontario Workers' Compensation Appeals Tribunal) (holding that the Tribunal was strictly bound by an earlier interpretation of a provision rendered by the Ontario Court of Appeal); Commissioner of Competition v Vancouver Airport Authority, 2017 CACT 6 at paras 145-50 (the Competition Tribunal held that it was bound by a 1994 Federal Court of Appeal decision regarding the existence of a class based privilege, and that stare decisis required it to follow that decision). This decision was reversed by the Federal Court of Appeal in Vancouver Airport Authority $v$ Commissioner of Competition, 2018 FCA 24, with the Court only briefly mentioning at para 67 that "[t]he Competition Tribunal stated, properly, that it is bound by decisions of our Court." However, it must be noted that decisions of the Competition Tribunal on questions of law are reviewed by the Federal Court of Appeal on a correctness standard (ibid at para 18).

(1978), 21 OR (2d) 364 (H Ct J (Div Ct)) [Frontenac].

SC 1975 , c 75.

Frontenac, supra note 62 at 367-68. It should be noted that the reasoning in Frontenac was based on the Supreme Court's decision in McLeod v Egan (1974), [1975] 1 SCR 517, a 1974 decision holding that, in judicial review of administrative action, the ultimate responsibility "lies with the Court, and ultimately with this Court, to determine what meaning the statute should bear" (ibid at 519, Laskin CJC). 1999 CanLII 14393 (Ontario Information and Privacy Commissioner) [Niagara Parks Commission]. See also Re Seguin (Township of), 2013 CanLII 64274 (Ontario Information and Privacy Commissioner), also concluding that it was unnecessary to decide the same stare decisis issue. 
Court's interpretation. The Commissioner recited the submissions of the parties regarding whether stare decisis ought to apply, but ultimately concluded that he did not need to resolve the issue in order to resolve the case. ${ }^{66}$

Another pre-Dunsmuir example comes from the Saskatchewan Court of Queen's Bench decision in Dairy Producers Co-operative Ltd. v. Teamsters, Dairy and Produce Workers, Local $834 .{ }^{67}$ That case involved an application of the patent unreasonableness standard of review to a decision of a labour arbitration board. The decision involved a situation where an employer, relying on an earlier Court of Queen's Bench decision, terminated a collective bargaining agreement on the understanding that the arbitration board would no longer have jurisdiction to settle any grievances. The arbitration board disagreed, finding that it did have jurisdiction. Justice Wimmer applied the patent unreasonableness standard of review and found that the board had not "interpreted a statute in a way that escapes the bounds of reason." ${ }^{68} \mathrm{He}$ could not find any established doctrine of stare decisis in administrative law that would dictate that the arbitration board was bound by the Court of Queen's Bench's earlier decision:

\footnotetext{
I am asked to hold that the Board's interpretation of s. 11(1)(m) of the Act is patently unreasonable because it did not adopt the view of Mr. Justice Hrabinsky. However, I am unable to find any doctrine of precedent stating that when a court and a specialist tribunal share jurisdiction to interpret a statute, a prior judicial interpretation is to be regarded as binding upon the tribunal.
}

For my part, I am satisfied to defer to the Board in this instance. I do not say whether the Board is right or wrong in its interpretation, only that it is not patently unreasonable to regard an agreed dispute resolution process as a condition of employment. ${ }^{69}$

However, it should be noted that this decision was overturned by an en banc panel of the Saskatchewan Court of Appeal on other grounds. ${ }^{70}$

There is, therefore, no definitive pre- or post-Dunsmuir ruling on the extent to which administrative decision-makers are bound by judicial decisions. While certain tribunals have addressed the issue in the pre-Dunsmuir era or in the context of correctness review, it does not appear that any administrative decision-maker has addressed the question of whether that tribunal is bound, as a matter of stare decisis, to a judicial decision holding that there is only one reasonable interpretation of a provision of that administrative decision-maker's statute.

On the academic side, Paul Daly has explored this issue of vertical stare decisis in Canadian administrative law to a limited extent. ${ }^{71}$ While most of Daly's article is addressed at horizontal stare decisis between administrative decision-makers and its effect on

Niagara Parks Commission, ibid.

(1992), 102 Sask R 202 (QB).

Ibid at para 16 .

Ibid at paras 19-20.

Dairy Producers Co-operative Ltd v Teamsters, Dairy and Produce Workers, Local 834 (1993), 113 Sask R 65 (CA). The Court of Appeal essentially overturned based on the finding of an unfair labour practice due to the employer's conduct before the arbitration board, not based on whether the arbitration board had jurisdiction to hear the grievance under the earlier Court of Queen's Bench decision.

See Daly, "Principle of Stare Decisis," supra note 11. 
reasonableness review, he seems to imply that an administrative decision-maker is bound as a matter of stare decisis to follow a court's decision where a court declares that a statute only has one reasonable interpretation:

Setting a judicial interpretation of a statutory provision in aspic threatens to compromise regulatory flexibility over time. The Canadian approach to stare decisis allows administrative decision-makers to change their positions in accordance with changing circumstances: "if a court has merely upheld an earlier tribunal interpretation of the provision as reasonable, the tribunal need not follow that interpretation if it prefers another interpretation that is also reasonable". Yet if a court carves the only possible, acceptable interpretation into a tablet of stone this inflexibility is eliminated as future administrative decision-makers are forever encumbered by the judicial edict. ${ }^{72}$

Implicit in this criticism is an assumption that the administrative decision-maker is bound to follow the court's interpretation. Daly goes on to argue that courts should refrain from declaring that a statute has only one reasonable meaning in order to avoid this issue of regulatory inflexibility. However, this article seeks to explore that which was largely assumed in Daly's work: is an administrative decision-maker actually bound by vertical stare decisis? Can it depart from a court's interpretation, even if the court declares that interpretation to be the only reasonable one? Should it be able to do so?

The Canadian jurisprudence has generally explored this issue in the context of remittance between a court and an administrative tribunal. While Daly's work has referenced vertical stare decisis in this context, he has not explored it in any detail. There does not appear to be any other recent Canadian academic work dealing with this issue. However, as the American courts have dealt with this issue extensively, it is useful to begin with a review of the American jurisprudence before determining the appropriate way to address the issue in Canada.

\section{The American Approach}

The American approach to stare decisis in administrative law was authoritatively articulated by Justice Thomas in the Court's 2005 decision of National Cable \& Telecommunications Association v. Brand $X$ Internet Services. ${ }^{73}$ However, in order to understand and explain the reasoning in Brand $X$, a brief detour to the seminal 1986 decision of Chevron U.S.A. Inc. v. Natural Resources Defense Council, Inc. ${ }^{74}$ is required. I will therefore begin by addressing the Chevron doctrine before outlining how the US Supreme Court resolved the issue of stare decisis in American administrative law. 


\section{CHEVRON}

In Chevron, Justice Stevens articulated a simple framework to govern all substantive judicial review of administrative interpretations of questions of law. The dispute itself concerned one phrase in the Clean Air Act Amendments of $1977^{75}$ : "stationary source." The Clean Air Act required certain states that had not reached acceptable air quality standards to establish a permit program that would regulate new or modified major stationary sources of air pollution. ${ }^{76}$ The Environmental Protection Agency (EPA), the agency tasked with administering the Clean Air Act, promulgated a regulation that encapsulated the "bubble concept," allowing these states to adopt a plant wide definition of the term "stationary source," such that all pollution-emitting devices within a single industrial plant would be covered by a single permit. ${ }^{77}$ This meant that an industrial plant could modify or install equipment without requiring additional permits so long as the total emissions from the plant did not increase. ${ }^{78}$

From this humble technical foundation came the most important administrative law doctrine in American jurisprudential history: the Chevron doctrine. As Justice Stevens explained, a court reviewing an administrative construction of a statute is always faced with two questions:

\footnotetext{
First, always, is the question whether Congress has directly spoken to the precise question at issue. If the intent of Congress is clear, that is the end of the matter; for the court, as well as the agency, must give effect to the unambiguously expressed intent of Congress. If, however, the court determines Congress has not directly addressed the precise question at issue, the court does not simply impose its own construction on the statute, as would be necessary in the absence of an administrative interpretation. Rather, if the statute is silent or ambiguous with respect to the specific issue, the question for the court is whether the agency's answer is based on a permissible construction of the statute. ${ }^{79}$
}

The first step of the Chevron doctrine requires the reviewing court to determine whether the statutory provision at issue is clear or ambiguous. If the statute is clear as to Congress' intention, "that intention is the law and must be given effect."

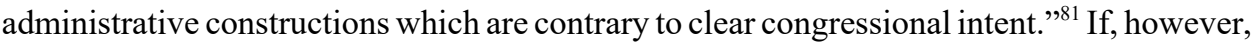
"Congress has explicitly left a gap for the agency to fill, there is an express delegation of authority to the agency to elucidate a specific provision of the statute by regulation." Congress intended to delegate the power to interpret a statute to an agency, that agency's construction of the statute is entitled to deference. ${ }^{83}$ The second step of the Chevron doctrine therefore requires a court to defer to the agency's interpretation if that interpretation is a reasonable one. ${ }^{84}$

Pub L No 95-95, 91 Stat 685.

Chevron, supra note 74 at 840 .

Ibid.

Ibid.

Ibid at 842-43 [footnotes omitted].

Ibid at 843, n 9 .

Ibid.

Ibid at $843-44$.

Ibid at 844 .

Ibid at 845 . 
Of course, despite its simple formulation, the Chevron doctrine is not without its problems or critics. Any Canadian lawyer tasked with applying the "simplified" standard of review analysis prescribed by Dunsmuir can sympathize. While it is not possible to chronicle even a fraction of the literature that has been written about Chevron, ${ }^{85}$ both positive and negative, it is worth noting that the Supreme Court of the US has continued to stand by Chevron deference as the authoritative framework for reviewing agency interpretations of statutes. Unlike Canadian administrative law, which one judge has described as "a never-ending construction site where one crew builds structures and then a later crew tears them down to build anew," ${ }^{, 6}$ the Chevron structure has stayed relatively stable in the American jurisprudential landscape. The benefit of this general doctrinal stability is that American courts have had the opportunity to address the stare decisis ramifications of the Chevron doctrine, culminating in the 2005 Brand $X$ decision.

\section{BRAND $X$}

In Brand X, the Supreme Court of the US considered whether the Federal Communications Commission (FCC) was bound by a decision of the Ninth Circuit Court of Appeals regarding whether cable modem service qualified as a "telecommunications service" for the purpose of regulation under the Communications Act of 1934. ${ }^{87}$ The Ninth Circuit held that cable modem service was a telecommunications service. The FCC, in a later ruling, held that Internet cable modem service providers were not telecommunications carriers. ${ }^{88}$ The question that the Supreme Court had to resolve was whether the FCC's departure from the Ninth Circuit's earlier ruling was permissible under Chevron.

Justice Thomas, writing for the majority, held that a judicial construction of a statute is only binding on an agency where the court had concluded at stage one of the Chevron framework that the statute was unambiguous and admitted of only one meaning. He stated:

A court's prior judicial construction of a statute trumps an agency construction otherwise entitled to Chevron
deference only if the prior court decision holds that its construction follows from the unambiguous terms of
the statute and thus leaves no room for agency discretion. This principle follows from Chevron itself. Chevron
established a "presumption that Congress, when it left ambiguity in a statute meant for implementation by
an agency, understood that the ambiguity would be resolved, first and foremost, by the agency, and desired
the agency (rather than the courts) to possess whatever degree of discretion the ambiguity allows".... Yet
allowing a judicial precedent to foreclose an agency from interpreting an ambiguous statute, as the Court of
Appeals assumed it could, would allow a court's interpretation to override an agency's. Chevron's premise
is that it is for agencies, not courts, to fill statutory gaps.... The better rule is to hold judicial interpretations
contained in precedents to the same demanding Chevron step one standard that applies if the court is
reviewing the agency's construction on a blank slate: Only a judicial precedent holding that the statute

Indeed, a search of "Chevron" in American law journals on HeinOnline produces close to 13,000 articles.

86 The Honourable Justice David Stratas, "The Canadian Law of Judicial Review: A Plea for Doctrinal Coherence and Consistency" (2016) 42:1 Queen's LJ 27 at 29.

87 Chapter 652, 48 Stat 1064 (codified as amended at 47 USC § 151). The Ninth Circuit decision at issue was AT\&T Corp v City of Portland, 216 F (3d) 871 (9th Cir 2000). 
unambiguously forecloses the agency's interpretation, and therefore contains no gap for the agency to fill, displaces a conflicting agency construction. ${ }^{89}$

However, a different analysis applies if there is no binding judicial precedent at Chevron step one. If the case is a "step two" case (that is, if a court cannot conclude that the statutory provision is clear) then a prior judicial decision holds no precedential weight. This flows logically from the fact that Chevron requires deference to the agency's construction if the statute is not clear - if the case is a step two case, the prior judicial precedent was one deferring to the agency's construction. Assuming the prior precedent upheld the agency's construction as permissible, there would be no stare decisis based reason to bind an agency to that judicial precedent in the future, though there may be other reasons for a court to question the changed precedent. ${ }^{90}$

American courts have thus come to a reasoned conclusion on the application of stare decisis between courts and agencies, at least in the general sense. There are, of course, numerous unresolved issues of stare decisis in American administrative law, but the large contours of the doctrine have been resolved. ${ }^{91}$ To recap: a judicial determination at Chevron step one that a statute is unambiguous is binding on an agency. Pursuant to Brand $X$, the agency cannot depart from this holding. A judicial determination at Chevron step two that an agency's interpretation is reasonable is not binding on that agency, and the agency is free to depart from it in the future. The stare decisis issues in Brand $X$ have, of course, been the subject of academic commentary and criticism in the US, ${ }^{2}$ but the fact remains that Brand

Ibid at 982-83 [citations omitted].

See Richard J Pierce Jr, "Reconciling Chevron and Stare Decisis" (1997) 85:7 Geo LJ 2225 at 2248-58 (summarizing conflicting approaches to stare decisis in step two of Chevron).

There is one very interesting contour that has been addressed by American courts, but has not yet been definitively resolved by the US Supreme Court. This is the issue raised in Gutierrez-Brizuela v Lynch, 834 F (3d) 1142 (10th Cir 2016) [Gutierrez-Brizuela]. In brief, the Court concluded that, where an agency rule was upheld at step two of Chevron by a reviewing court and where the agency later decides to depart from that rule, the agency's new rule does not take general legal effect until it is affirmed by a reviewing court at step 2 of Chevron. Until it is affirmed, the agency's rule is prospective in nature only: it does not apply to individuals whose claims arose prior to the agency's change in interpretation. An exploration of the fascinating issues raised in Gutierrez-Brizuela about the interrelationship between the prospective versus retrospective nature of a changed administrative decision vis-à-vis an earlier judicial decision affirming the earlier rule as reasonable is, unfortunately, outside of the scope of this article. It is, however, another stare decisis issue that Canadian courts will have to grapple with if they choose to continue utilizing a "one reasonable interpretation" model of judicial review on questions of law.

For those interested in exploring the stare decisis ramifications of Brand $X$ further, see e.g. James Dawson, "Retroactivity Analysis After Brand X" (2014) 31:1 Yale J Reg 219; Wesley Sze, "Did X Mark the Spot?: Brand $X$ and the Scope of Agency Overrides of Judicial Decisions" (2016) 68:1 Stan L Rev 235; Doug Geyser, "Courts Still 'Say What the Law Is': Explaining the Functions of the Judiciary and Agencies after Brand X" (2006) 106:8 Colum L Rev 2129; Michael C Harper, "Judicial Control of the National Labor Relations Board's Lawmaking in the Age of Chevron and Brand X" (2009) 89:1 BUL Rev 189; Christopher J Walker, "Avoiding Normative Canons in the Review of Administrative Interpretations of Law: A Brand X Doctrine of Constitutional Avoidance" (2012) 64:1 Admin L Rev 139; Claire R Kelly, "The Brand X Liberation: Doing Away with Chevron's Second Step as Well as Other Doctrines of Deference" (2010) 44:1 UC Davis L Rev 151; Richard W Murphy, "Abandon Chevron and Modernize Stare Decisis for the Administrative State" (2017) 69:1 Ala L Rev 1; Harold M Greenberg, "Why Agency Interpretations of Ambiguous Statutes Should Be Subject to Stare Decisis" (2012) 79:3 Tenn L Rev 573; Daniel J Gifford, “The Emerging Outlines of a Revised Chevron Doctrine: Congressional Intent, Judicial Judgment, and Administrative Autonomy” (2007) 59:4 Admin L Rev 783; Todd S Aagaard, "Factual Premises of Statutory Interpretation in Agency Review Cases" (2009) 77:2 Geo Wash L Rev 366; Elizabeth V Foote, "Statutory Interpretation or Public Administration: How Chevron Misconceives the Function of Agencies and Why It Matters" (2007) 59:4 Admin L Rev 673; "How Chevron Step One Limits Permissible Agency Interpretations: Brand $X$ and the FCC's Broadband Reclassification" (2011) 124:4 Harv L Rev 1016; "Implementing Brand X: What Counts as a Step One Holding?" (2006) 119:5 Harv L Rev 1532. 
$X$ is the law in the US. The question this article seeks to explore is whether the reasoning of the US Supreme Court in Brand $X$ ought to be transposed into Canada.

The conclusions in Brand $X$ were obviously derived in the American legal system. While American and Canadian administrative law may be of the same species, the two are different breeds. ${ }^{93}$ The American principles are not necessarily transposable into Canadian administrative law, but they do provide an example of how this problem has been confronted in a relatively similar administrative law system, and they provide a possible route for Canada to follow when Canadian courts are inevitably confronted with this same issue. However, since the American solution was obviously created on American administrative law principles, the next section will explore the question of how this issue can be addressed in Canada using Canadian administrative law principles.

\section{Possible Solutions}

In proposing and evaluating the following potential solutions, I am addressing only the stare decisis implications of a judicial decision that utilizes the reasonableness standard of review. I have placed these potential solutions within the abstract principles of reasonableness review outlined in Part II, exploring whether and how these potential solutions can adequately respect and balance the foundational principles of reasonableness review in the Canadian administrative law system.

However, as a caveat, the following discussion does not address the stare decisis implications of judicial review on a question of statutory interpretation using the correctness standard of review. This is because the two foundational principles of judicial review both favour strict vertical stare decisis on questions of law that are resolved on correctness review: there is no justification for deference to the administrative actor based on the principle of legislative intent, and correctness review gives effect to rule of law considerations. Correctness review also gives effect to the legislative intent behind whatever provision is being interpreted. Correctness review necessarily implies that the administrative actor has no interpretive latitude within its specialized field, and that the administrative actor must defer to the court's decision.

Further, this section does not address the stare decisis implications of a judicial decision finding that a statutory provision admits of multiple reasonable interpretations and affirming (or quashing) an administrative decision on that basis. The Federal Court of Appeal has held that an administrative actor is free to depart from a judicial decision affirming one interpretation as reasonable, as the administrative actor is always free to adopt another 93 For example, the type of deference owed in the US depends, in part, on the formality of the particular
agency's rule making process - Chevron applies to formal adjudication, but what is known as "Skidmore deference" applies to less formal administrative rulings: see United States v Mead Corp, 533 US 218 at 230-32 (2001). There is no such distinction in Canadian administrative law. 
reasonable interpretation in a future case. ${ }^{94}$ This conclusion is entirely sensible and admits of no stare decisis problems.

Finally, this section does not address the issue of a reviewing court that remits a matter to an administrative decision-maker to render another decision in light of the court's interpretation. This issue was addressed by the Supreme Court in Canada Bread Company and, though framed in stare decisis terms by the majority, it is actually more akin to the doctrine of issue estoppel. ${ }^{95}$ In this sort of situation, the reviewing court's directions are part of the remedy granted for an unreasonable decision, as those directions accompany the remittance of the decision back to the original decision-maker. Whether they are strictly binding on a future administrative decision-maker interpreting the same provision in a dispute between different parties is precisely the question that I am exploring in this article.

\section{A. Hard Stare Decisis}

The first solution is to adopt the reasoning in Brand $X$ and apply it to Canadian administrative law. In Brand $X$, the US Supreme Court held that a judicial determination on step one of Chevron is binding on all future agency determinations. Once a court determines that a provision is unambiguous, the court's interpretation forever prevails - or, at least, until the court decides to modify it. Adopting this reasoning in Canada would mean that, once a court applies reasonableness review (or correctness review) and finds that a statutory provision admits of only one reasonable (or correct) interpretation, that is the end of the story. The administrative decision-maker is forever bound by that determination, or at least until another reviewing court decides to overturn that interpretation.

As this is the solution that is likely the most comforting to common law lawyers who are distrustful of administrative actors rendering authoritative interpretations of statutory provisions, it is the one that I will explore in the greatest detail.

\section{THE RULE OF LAW AND LEGISLATIVE INTENT}

The idea of hard vertical stare decisis forever binding an administrative decision-maker to a court's "one reasonable interpretation" is consistent with the principles underpinning the doctrine of stare decisis, as it promotes order and consistency in the law by ensuring that the administrative decision-maker and courts always act consistently. It protects the settled expectations of individuals, as they can guide their behaviour according to the judicial interpretation without fear that the administrative decision-maker will upset that interpretation. This has significant benefit in the regulatory realm, as the extreme technicality admits of multiple reasonable interpretations and the tribunal's interpretation is still quashed as unreasonable, it may not be open to the tribunal to select that interpretation in the future - it depends on why the court declared the administrative interpretation to be unreasonable.

95 See Danylukv Ainsworth Technologies Inc, 2001 SCC 44 at para 25 (issue estoppel has three elements: (1) that the same question was decided; (2) that the judicial decision creating the estoppel was final; and (3) that the parties to the judicial decision were the same parties as those before the proceeding in which the estoppel was raised). Issue estoppel is based on res judicata and the need for finality in proceedings. While similar principles also underlie the doctrine of stare decisis, they apply in a somewhat different manner. 
of many regulatory requirements already makes compliance difficult for individuals and corporations. Adding an element of uncertainty by allowing administrative decision-makers to alter and undermine judicial decisions without notice would only make compliance even more difficult. It also reduces the cost of the administrative state by reducing the workload for administrative decision-makers, reducing the need for counsel to advise litigants about potential uncertainty, and reducing the uncertainty for litigants themselves. It is, therefore, the approach that best protects the reliance interest underlying the doctrine of stare decisis, and arguably, best protects the rule of law. Once a court says that a provision means X, individuals can order their affairs on the understanding that the provision will always mean $\mathrm{X}$. Order and certainty are guaranteed.

But against those rule of law benefits, this solution may be the most detrimental to the principle of legislative intent and, therefore, detrimental to the principled rationale for reasonableness review. If an administrative actor is bound by a judicial interpretation of that administrative actor's home statute, the administrative actor is required to defer to the court on that question in the future. The reasonableness review that gave rise to the judicial decision was premised on deference to the administrative decision-maker. "Deference" to one interpretation ultimately negates deference in the future between the court and administrative actor on that very same question.

Further, the legislature created an administrative decision-maker and imbued it with the power to implement and interpret a complex scheme - it is reasonable for the legislature to expect that, having created the administrative actor, that actor will "have or will develop a considerable degree of expertise or field sensitivity to the imperatives and nuances of the legislative regime. ${ }^{" 96}$ If deference is premised on respect for the legislature's intention to vest the power to make a particular decision in another, applying stare decisis to bind the administrative decision-maker to the legal interpretation rendered by a court undermines the purpose of deferential review altogether. The decision of the generalist court binds the specialist administrative actor, precluding the specialist from applying its expertise to reach a differing conclusion that may be justified in light of its specific policy goals and regulatory structure. ${ }^{97}$ This turns the principled rationale for deferential review on its head.

On a principled level, then, hard vertical stare decisis tends to prioritize the rule of law over legislative intent and undermine the principled rationale for deferential review in the first place. It undercuts one of the core pillars of judicial review, leaving the doctrine on a shakier foundation.

\section{Practical AND TheORETICAL FlaWS With THIS MOdEL}

In addition to these principled problems, there is one significant theoretical flaw in the hard stare decisis model: it must assume that the court's interpretation is correct. Why is the court any more capable than the administrative decision-maker of deciding what the

97 See generally Paul Daly, "Unreasonable Interpretations of Law" (2014) 66 SCLR (2d) 233 at 269 (describing the folly in applying judicially developed principles of statutory interpretation on reasonableness review to determine the one reasonable interpretation of a statutory provision). 
legislature intended when it enacted a particular provision? Simply because the court is applying judicially developed principles of statutory interpretation? The modern approach to statutory interpretation is hardly a mechanism by which a clear and objective meaning can be determined, as few questions of statutory interpretation admit of only one possible answer. ${ }^{98}$ Even if a statutory provision appears to one judge to have one clear meaning, it may not be so clear to another. ${ }^{99}$ Or, even worse, judges may apply the same principles of statutory interpretation to the same statutory provision and disagree on the single correct or single reasonable interpretation of that provision. ${ }^{100}$ If courts cannot reliably determine the meaning of a provision, a court's claim to have divined the one reasonable - or correct interpretation of that provision should be viewed with some skepticism.

This hard stare decisis solution is based on the flawed belief that the court has a greater ability than the administrative decision-maker to divine the one reasonable interpretation of a statute, or that any judicial interpretation of a statute is the correct one. This implicitly reflects a Marshallian ${ }^{101}$ understanding of the relationship between courts and administrative actors, namely that "[i]t is emphatically the province and duty of the judicial department to say what the law is." 102 While such a position may be consistent with American Chevron logic, ${ }^{103}$ it does not sit comfortably with the Canadian rationale for deference on questions of law, as this rationale is based on deference to the administrative decision-maker's accumulated expertise and specialized policy knowledge.

Indeed, if the administrative decision-maker uses that expertise and specialized policy knowledge to conclude that the legislature actually meant $\mathrm{Y}$ when it said X, why should that conclusion be automatically quashed if a court had declared that the statute means $\mathrm{Z}$ ? In many respects, the administrative decision-maker may be more capable of giving effect to specific legislative intent than the court. ${ }^{104}$ As the Supreme Court has noted, "the broad

This is not to say that no question of statutory interpretation can admit of one answer. For example, if a statute says that residential garbage will only be picked up every Wednesday, there is no plausible interpretation of the statute that would result in residential garbage being picked up on a Thursday. The statute is clear. However, for obvious reasons, there are very few such clear questions of statutory interpretation that end up being litigated before courts or administrative tribunals.

$99 \quad$ See e.g. Allen $v$ Newfoundland and Labrador (Workplace Health, Safety \& Compensation Review Division, 2014 NLCA 42 at para 46 [Allen].

100 The Court in Allen, ibid, pointed to the House of Lords' decision in Ellerman Lines Ltd v Murray (1930), [1931] AC 126 (HL) as an example of this. In that case, three judges disagreed on the meaning of the phrase "in fact employed," with three different judges arguing that each of their interpretations reflected the "plain meaning" of that phrase.

101 Referring to Chief Justice Marshall of the US Supreme Court. Of course, as some have argued, Chief Justice Marshall's logic in Marbury v Madison, 5 US 137 (1803) [Marbury] is far more nuanced than a simple "judges must decide the law" rule: see e.g., Aditya Bamzai, "Marbury v. Madison and the Concept of Judicial Deference" (2016) 81:4 Mo L Rev 1057 (arguing that the foundations for the modern idea of deference to administrative decisions are found in Marbury). However, it is Chief Justice Marshall's famous quote in Marbury that has defined his judicial review legacy. Marbury, ibid at 177.

103 See e.g. Elizabeth Garrett, "Legislating Chevron" (2003) 101:8 Mich L Rev 2637 at 2639 (explaining how the doctrine of congressional delegation espoused in Chevron reconciles the logic in Marbury with modern administrative law, though ultimately proposing a revision to the Chevron analysis). The American approach to stare decisis on questions of law tends to reflect Justice Brandeis' famous observation that "[i]t is usually more important that a rule of law be settled, than that it be settled right" (Di Santo $v$ Pennsylvania, 273 US 34 at 42 (1927)).

104 But, of course, not in all respects. There are numerous administrative decision-makers that do not have the power to decide questions of law, or very rarely decide questions of law. These administrative decision-makers may not be capable of adequately resolving a question of pure statutory interpretation. In these sorts of scenarios, the hard stare decisis justification makes some sense. But, arguably, in these scenarios the legislature would have always intended for these decision-makers to be bound by judicial determinations of questions of law, as the legislature did not imbue them with any legal expertise. It 
policy context of a specialized agency infuses the exercise of statutory interpretation such that application of the enabling statute is no longer a matter of 'pure statutory interpretation." 105 There is a significant policy context to any question of statutory interpretation or application within an administrative regulatory field, and the administrative decision-maker may be far better placed than a court to give effect to that context.

This is not to say that the administrative decision-maker's interpretation is infallible, as administrative actors are quite capable of reaching unreasonable interpretations of statutory provisions, even with their home statutes. An administrative decision-maker's interpretation of a statute is no more automatically reasonable than a court's interpretation is automatically correct. However, the point is that the application of hard stare decisis is premised on an assumption that it is the court's interpretation that is infallible — once the "one reasonable" meaning of a provision has been settled by the courts, it is the de facto correct interpretation. This premise is belied by the inherent subjectivity of the modern approach to statutory interpretation.

Finally, on a practical level, the enforcement of hard vertical stare decisis would realistically require that correctness review be applied when reviewing a second administrative interpretation against the sole reasonable interpretation declared by a court, as it could not admit of any deference to the administrative decision-maker's interpretation. If the administrative decision-maker's interpretation is being judged against a court's earlier interpretation, the court's task on judicial review is to ensure that the administrative decisionmaker has not departed from the court's earlier interpretation. This means that, if we are to accept that a court's declaration of "one reasonable interpretation" is strictly binding on administrative decision-makers in the future, an administrative decision-maker's later decision to revisit or depart from that interpretation must be reviewed on a correctness standard. The court must determine whether the second administrative decision accords with the court's interpretation of the provision. If it does not, the second administrative decision must be quashed. Whatever courts may choose to call it, this is correctness review.

The end result is that hard vertical stare decisis would mandate that two different standards of review be applied to the same question decided by the same decision-maker: reasonableness review on the first review, and correctness review on the second. This seems untenable. The application of reasonableness review to a question of law ends up resulting in correctness review later applying to that same question of law. The justifications for applying reasonableness review in the first place tend to fall away. The need for order,

would, therefore, actually be consistent with the principle of legislative intent for these decision-makers to defer to courts on questions of law. If one were to actually apply the principles of judicial review in this scenario, it would theoretically mandate correctness review on all questions of law decided by those administrative decision-makers because the legislature never intended courts to defer to the administrative actor on those questions of law - a proposition that the Supreme Court has so far stubbornly resisted.

105 Council of Canadians with Disabilities v VIA Rail Canada Inc, 2007 SCC 15 at para 92 [Council of Canadians with Disabilities], citing Barrie Public Utilities v Canadian Cable Television Assn, 2003 SCC 28 at para 86, Bastarache J, dissenting. However, at least one judge has recently suggested that reasonableness review on questions of law requires administrative decision-makers to apply judicially developed principles of statutory interpretation and to refrain from infusing their own personal policies or political preferences into the interpretive exercise: see Schmidt v Canada (AG), 2018 FCA 55 at paras 24-28. The extent to which the statutory interpretation principles from Council of Canadians with Disabilities have survived the reasonableness revolution post-Dunsmuir is an open question. 
certainty, and stability in the law is a concern that motivates correctness review, not reasonableness review. If these values trump deference where a court declares that there is only one reasonable interpretation of a statute, then there is little justification for deference on that question in the first place.

\section{B. No StARE Decisis}

The second solution is the complete opposite of the first: even if a court were to find that a statute admits of only one reasonable interpretation, an administrative decision-maker would not be bound in the future by the court's interpretation. Instead, the administrative decision-maker would be free to depart from the court's interpretation, with the administrative decision-maker's new decision freshly reviewable on the reasonableness standard. That is not to say that the administrative decision-maker would not be bound by the court's interpretation in a remittance scenario. ${ }^{106}$ Instead, this proposal posits that, where the matter is res judicata, a future administrative decision-maker is not bound by the court's interpretation of a statutory provision in a future case, even if the court decrees its interpretation to be the only reasonable one. The court's interpretation would only be binding in the particular proceeding in which the court's decision was rendered, but it would have no precedential authority beyond that. The administrative decision-maker would be free in the future to adopt whatever interpretation it wished of a particular statute, subject to fresh review for reasonableness.

This solution essentially proposes the equivalent of horizontal stare decisis between courts and administrative tribunals on questions of law. If horizontal stare decisis were to apply between courts and administrative decision-makers, an administrative decision-maker would be free to depart from a judicial decision finding that there was only one reasonable interpretation of a statutory provision. If the administrative decision-maker believed the court's interpretation was incorrect, the administrative decision-maker could, in theory, adopt a different interpretation - even the interpretation that was originally rejected by the court. While the administrative decision-maker's second interpretation would presumably be subject to judicial review on the reasonableness standard, it would not be deemed unreasonable solely because it conflicted with the first reviewing court's decision. Instead, the second reviewing court would be required to conduct reasonableness review anew and determine whether the second interpretation was reasonable.

\section{THE RULE OF LAW AND LEGISLATIVE INTENT}

The idea of horizontal stare decisis between courts and administrative decision-makers is attractive because it is consistent with the deferential underpinnings of reasonableness review. It treats courts and administrative decision-makers as interpretive equals, and allows for a true application of reasonableness review to all interpretations of the same statutory provision rendered by the same administrative decision-maker. This avoids the problem of

106 See Canada Bread Company, supra note 50. The Supreme Court has been clear that, where a court remits a matter to an administrative decision-maker to decide in light of the court's decision, the administrative decision-maker is bound by the court's decision as long as the court's decision remains good law. 
varying standards of review that would result from an application of hard vertical stare decisis.

Further, applying horizontal stare decisis to allow for an administrative decision-maker to depart from a judicial interpretation where it deems it prudent to do so would mean that neither the court nor the administrative decision-maker can claim paramount authority when interpreting the administrative decision-maker's home statute. The principle of legislative intent is respected because the administrative decision-maker is given freedom and flexibility to interpret its statute and develop policy within its own field. It would also recognize that many administrative decision-makers have an equal (if not superior) ability to give effect to the legislature's intent in determining the meaning of particular provisions of their home statutes. This is especially true for administrative decision-makers protected by a privative clause, as the privative clause is meant to signal the legislature's intent that the question at issue be resolved by the administrative decision-maker rather than the courts. ${ }^{107}$

However, against those benefits, the idea of horizontal stare decisis between courts and tribunals undermines the rule of law as it allows for the possibility of perpetual uncertainty in the law. Even if a court settles the meaning of a statutory provision on judicial review, the administrative decision-maker may decide to depart from that judicial decision in the future without notice to individuals who may be relying on the judicial interpretation. This could lead, in theory, to a perpetual cycle of disagreement where a tribunal maintains that a statutory provision means $\mathrm{X}$, while reviewing courts maintain that the provision means $\mathrm{Y}$. If there is no entity capable of definitively settling the meaning of the law, the rule of law values of certainty and predictability are undermined. ${ }^{108}$ Even if the court says the provision means $X$, individuals have no guarantee that the provision will continue to mean $X$. Individuals will find it impossible to rely on the law to guide their behaviour, as it is impossible to know on any particular day what the law means. This renders the law intolerably vague. Horizontal stare decisis is therefore consistent with the principle of legislative intent, but quite inconsistent with the principle of the rule of law. Like strict vertical stare decisis, it tends to skew the balance of the foundational principles of judicial review.

\section{Constitutional AND PRACTICAL OBJECTIONS}

There are numerous other problems with the idea of horizontal stare decisis between courts and administrative decision-makers. I will focus on two: a constitutional problem and a practical problem. The strongest objection to the idea of horizontal stare decisis between courts and tribunals is a constitutional one. As the Supreme Court held in Crevier and Reference Re Residential Tenancies Act, $1979,{ }^{109}$ the power to engage in judicial review is a supervisory power that lies at the core of section 96 of the Constitution Act, $1867 .{ }^{110}$ The jurisdiction that lies at the core of section 96 cannot be removed or altered by Parliament or

Dunsmuir, supra note 1 at para 52.

To be clear, however, I am referring here to the precedential effect of the reviewing court's decision, not the rationale for the reviewing court's decision to intervene and settle the meaning of the law. The latter is about the selection of the appropriate standard of review. This article takes as a given that the reasonableness standard of review applies. 
by the courts themselves. ${ }^{111}$ Creating a rule of horizontal stare decisis between courts and administrative tribunals arguably removes the "supervisory" aspect of judicial review that lies at the core of section 96. If a tribunal is free to disregard a reviewing court's decision, the reviewing court's role in maintaining the rule of law is undermined. The reviewing court no longer exercises a general supervisory role, but instead is relegated to a sort of administrative appeal tribunal, unable to issue generally-binding rulings. This does not accord with the Supreme Court's understanding of the superior courts as "the foundation of the rule of law itself," 112 capable of issuing generally binding rulings on matters that lower courts and statutory courts cannot touch. This implies that the power to bind lower courts (and presumably tribunals) is one that lies at the heart of section 96 courts. ${ }^{113}$ In other words, horizontal stare decisis between courts and tribunals may very well be unconstitutional.

This solution also creates significant practical problems for reviewing courts because it would trigger stare decisis problems between reviewing courts. An administrative decisionmaker may not be bound by a decision of a higher court, but a lower court is still bound by the higher court's decision. This leads to the possibility of a stare decisis quagmire. If the Supreme Court or an appellate court decides that a statute admits of one reasonable interpretation, horizontal stare decisis would allow the administrative decision-maker to depart from the Supreme Court's interpretation if it decides that the Supreme Court was incorrect. But a reviewing court is not so free: if the second tribunal again decides, for example, that its statute permits it to award costs, a court on judicial review would arguably be bound by the Supreme Court's interpretation as a matter of stare decisis. Even if the reviewing court were to agree that the second tribunal's interpretation was reasonable, it would arguably be precluded from reaching that conclusion as to do so would contradict a Supreme Court decision as to the sole reasonable interpretation of that statute. The reviewing court would be placed in an impossible position: it must either disregard a binding Supreme Court ruling or it must quash a reasonable administrative decision. This incentivizes endless litigation and may incentivize the legislature to remove more political and legal questions from the reach of the courts. ${ }^{114}$ The horizontal stare decisis solution, while perhaps theoretically attractive, is constitutionally and practically untenable.

\section{COMmon Law Stare Decisis}

The third proposed solution is a relaxed version of the first, and a more stringent version of the second solution. Rather than binding an administrative tribunal to a court's one reasonable interpretation of its home statute, until and unless the court later changes its mind, this proposal would treat the administrative actor akin to a lower court. The administrative

$111 \quad$ MacMillan Bloedel Ltd v Simpson, [1995] 4 SCR 725 at para 15.

$112 \quad$ Ibid at para 37.

113 Though, of course, this issue has never been squarely decided by the Supreme Court. Likely because no one has yet taken the heretical step of suggesting that a tribunal should not be strictly bound by a decision of a superior court on a question of law.

114 If a legislature disliked the judicial approach to a particular issue, it could, in theory, remove that issue from the jurisdiction of the courts and empower an administrative decision-maker to decide it. Many administrative decision-makers are appointed by the executive and may legitimately give effect to political preferences in their decision-making. If the administrative decision-maker was not strictly bound by certain interpretations rendered by a court on judicial review, these political and legal questions could effectively be removed from judicial oversight altogether. This severely weakens the constitutional constraints that an independent judiciary ostensibly imposes on the executive and legislative branches of government. 
actor could depart from the reviewing court's one reasonable interpretation of its statute in certain, limited circumstances, whether they be the common law exceptions to stare decisis or an appropriate administrative law modification to those common law exceptions.

The common law exceptions to stare decisis are those scenarios where it is permissible for a lower court to depart from a binding ruling of a higher court where the ruling of the higher court cannot be distinguished. Traditionally, a lower court was only entitled to depart from a binding ruling of a higher court where that higher court's decision was given per incuriam, that is, "in ignorance of some binding authority." 115 The Supreme Court added another exception in Bedford, stating that a lower court was entitled to depart from a binding authority of a higher court "if new legal issues are raised as a consequence of significant developments in the law, or if there is a change in the circumstances or evidence that fundamentally shifts the parameters of the debate."116

Applying the common law stare decisis exceptions to reasonableness review on questions of law would mean that an administrative actor is free to depart from a court's "one reasonable" interpretation if the court overlooked some sort of binding authority in reaching that interpretation. It would also mean that an administrative decision-maker can depart from the court's interpretation where the law, circumstances, or evidence changes so significantly as to fundamentally shift the parameters of the debate. The latter exception goes a long way in militating against the vice of "[s]etting a judicial interpretation of a statutory provision in aspic," 117 as it allows for the possibility of changes to that interpretation based on changing circumstances. The administrative decision-maker is not faced with the possibility of being hamstrung by an outdated judicial interpretation until a court decides to change the law.

As this solution is a middle ground between the first two, I do not intend to retread the same discussion of foundational principles. However, applying common law stare decisis rules rather than no stare decisis rules would mitigate the deleterious effect of hard vertical stare decisis on the principle of legislative intent while bolstering the protection for the rule of law that may be lacking in the horizontal stare decisis scenario. It would also avoid the paradox for reviewing courts created by the horizontal stare decisis scenario, as the reviewing court could rely on the same common law exception identified by the administrative decision-maker to justify departure from an otherwise binding appellate ruling. Finally, it would avoid the necessary application of correctness review to the second decision, as reasonableness review would require careful and respectful attention to be paid to the reasoning for departing from the first interpretation, and if it was reasonable to do so in the circumstances, deference should result.

Of course, an administrative decision-maker seeking to rely on one of these exceptions to depart from a reviewing court's interpretation would face an uphill battle in doing so. It would have to adequately explain and justify its decision to depart from the judicial interpretation in order to enable a reviewing court to ensure that the administrative decision-

Caswell, supra note 47 at para 36, citing Broome v Cassell \& Co, [1972] AC 1027 (HL). See also Royal Bank of Canada v Trang, 2014 ONCA 883, rev'd 2016 SCC 50 (with the court splitting over whether the per incuriam exception ought to have been applied). 
maker had a sufficient basis to justify departing from an otherwise binding judicial interpretation. This should not be the sort of situation where a court may look at "the reasons that could be offered" in support of an administrative decision. ${ }^{118}$ Looking to implied reasons to justify a departure from an otherwise binding rule would render any concept of stare decisis incoherent, as it would be impossible to distinguish between a legitimate departure from a pre-existing rule and an unreasonable failure to follow a binding rule. It would shift the burden to the reviewing court to justify departure from a rule that was either endorsed by the reviewing court itself or by an appellate court. The reviewing court would bear the burden of trying to justify why stare decisis ought not to apply. This cannot be correct. If an administrative decision-maker chooses to depart from a binding interpretation, it ought to bear the burden of explicitly explaining why a common law exception to stare decisis is met.

However, the problem with simply applying the common law exceptions to an administrative decision-maker is that it transposes a rule developed in the judicial context into the administrative context wholesale, without considering its appropriateness in light of the fundamental differences between courts and administrative actors. It treats administrative actors as if they were simply funny looking lower courts. Take, for example, the per incuriam exception. Traditionally, this exception allows a court to depart from a binding ruling based on judicial or statutory authority that, had it been considered, would have led to a different result. Applying it strictly to administrative actors assumes that administrative actors and courts have the same interpretive perspective and interests, such that the court's interpretation would match the administrative actor's changed interpretation had they simply considered the same legal rules. This does not grant any room to the administrative decisionmaker to exercise its legitimate policy-making role, nor give effect to its institutional expertise in interpreting and applying its home statute.

Because the common law exceptions to stare decisis are common law rules, they are amenable to future modification and adaption. One future modification could be the development of a uniquely administrative approach to stare decisis. Translating the traditional common law exceptions into new administrative law exceptions to stare decisis could give appropriate effect to the institutional expertise considerations that underpin deferential review, as institutional expertise would otherwise not factor into the common law exceptions.

For example, the per incuriam exception to stare decisis ordinarily only applies to existing binding rules that a court may have overlooked. ${ }^{119}$ If this were translated into an administrative law concept, one could argue that, had the court had the expertise of the decision-maker, it would have realized the problems and impossibilities that its interpretation would create and it would have adopted a different one. ${ }^{120}$ This rationale supplements the traditional common law exception with administrative expertise, allowing for the possibility

Alberta (Information and Privacy Commissioner) v Alberta Teachers' Association, 2011 SCC 61 at para 54.

Polowin Real Estate, supra note 43 at para 111.

This was precisely the situation confronted by the Ontario Information and Privacy Commissioner in Niagara Parks Commission, supra note 65. In that case, the Divisional Court had rendered an interpretation of the Privacy Commissioner's home statute that was controversial with future litigants seeking access to private records. While the parties in the particular Divisional Court case did not appeal it, future litigants expressed strong disagreement with the conclusion reached by the Divisional Court on the meaning of the Privacy Commissioner's home statute and asked the Privacy Commissioner to decline to follow that decision. 
that an administrative decision-maker can overturn the court where the court simply did not know what sort of havoc its decision would wreak. The court may not have overlooked any sort of binding rule, but it did overlook administrative realities in making its decision. ${ }^{121}$

There is a nuanced distinction between the normal comity that ordinarily applies in horizontal stare decisis situations and the possibility of an administrative law per incuriam exception to vertical stare decisis. The rationale for departing from the judicial ruling in the per incuriam scenario is not that the administrative decision-maker, though respectful of the judicial ruling, believes it to be wrong and is able to provide a justified and intelligible explanation of why it is wrong and why a different interpretation is preferred. The rationale is that the administrative decision-maker is able to point to something that was overlooked by the court in making its decision: for example, an unanticipated consequence of the court's ruling that creates significant regulatory difficulty for the administrative decision-maker. Unlike horizontal stare decisis, this exception would start from the premise that the court's decision is binding on the administrative decision-maker, and would require the administrative decision-maker to specifically point to something that was overlooked by the court and that would have been likely to have changed the court's decision had it considered it. It is impossible to identify in advance all of the different things that could fit within this idea of a revised per incuriam exception. The point is simply that the per incuriam exception may be adaptable for the administrative law realm.

The "changed circumstances" exception from Bedford may also have an administrative law sibling, though perhaps one with slightly stricter rules. In Bedford, departure from binding precedent was justified based on a change in the law, a change in the evidence, or a significant change in circumstances. ${ }^{122}$ One could add that, in the administrative law realm, a departure from binding precedent could also be justified based on a significant shift in regulatory policy, new direction from the executive, or a newly evolving understanding of the meaning of a particular provision based on the decision-maker's repeated application of that provision. This opens the door a little wider for an administrative decision-maker to justify a changed interpretation of a statutory provision, though the administrative decisionmaker would still be required to offer compelling reasons for that change.

This final proposal is an aspirational one. It is based on an idealized understanding of the process of judicial review that may not ultimately accord with reality, and that may need to be continually revised and adapted for the myriad of administrative decision-makers that exist today. For example, the idea that a changed administrative interpretation based on one of these exceptions would be upheld on reasonableness review depends, in large part, on the

"Administrative realities" is obviously a vague phrase open to many interpretations. However, it is premised, at base, on an assumption that the administrative actor will be capable of articulating specifically why the judicial decision does not accord with the realities of the day-to-day exercise of regulatory functions or policy development within that particular administrative field. For example, in Niagara Parks Commission, ibid, one could argue that refusing to allow the contextual factors in section 21(2) of the Freedom of Information and Protection of Privacy Act, RSO 1990, c F.31 to rebut the presumption of an unjustified invasion of privacy in section 21(3) undermined the Privacy Commissioner's ability to effectively balance the privacy of individuals against the public's right of access to information. 
reviewing judge possessing the virtue of judicial humility ${ }^{123}$ - a quality that some judges may lack. It is also premised on a fictional conception of an administrative actor with a monolithic understanding of its own expertise and the needs of its regulatory field. Such a premise obviously does not accord with the realities of most administrative actors. There may be a fundamental difference of opinion between panels or decision-makers - even those of the same institution — as to what legal rule would best fit that actor's regulatory field.

Further, it is based on an idealistic conception of a dispassionate administrative actor, which disregards the political realities of many administrative actors. For example, many administrative decision-makers are appointed by the executive and hold office at the pleasure of the executive. ${ }^{124}$ Others, such as Ministers, are explicitly political actors. ${ }^{125}$ These administrative decision-makers may favour one interpretation over another simply for political reasons. They may give little thought to the ideal interpretation of a statutory provision in light of the regulatory realities of their fields, instead preferring to adopt the interpretation that best accords with their political preferences. This aspirational proposal does not account for the legitimate political preferences of some administrative decisionmakers and how they ought to be weighed on judicial review. The inherently political nature of many administrative decision-makers may ultimately negate any justification for a more relaxed version of stare decisis on questions of law, though, of course, such a consideration may also negate any justification for deference on questions of law altogether. The point is simply that this articulation of a possible solution to the stare decisis problem is an abstract one: its practical contours must be further explored and defined before it can realistically be implemented. But this proposal holds the potential to provide a principled and workable solution to the stare decisis problem in administrative law. It is one that is worthy of more attention and study.

\section{Conclusion}

This article is not about the standard of review. ${ }^{126}$ It has nothing to say on how a court should select the standard to apply, nor whether and when a court ought to conclude that one or more reasonable interpretations are possible. This article takes as a given the fact that courts have applied and will continue to apply reasonableness review to conclude that only one reasonable interpretation of a statutory provision is available. Taking this premise as a given, this article has explored the difficult question of what should happen next. This is a question that Canadian courts have not yet squarely addressed, and it is one that will need to be resolved in the years ahead if the current fashion of reasonableness review is to continue.

( Dworkin's 'Moral Reading' of the Constitution" (1997) 65:4 Fordham L Rev 1269 ("an essential element of responsible judging is a respect for the opinions and judgments of others, and a willingness to suspend belief, at least provisionally, in the correctness of one's own opinions" at 1292). For example, members of the National Energy Board are appointed for seven year terms, but "may be removed at any time by the Governor in Council on address of the Senate and House of Commons": National Energy Board Act, RSC 1985, c N-7, s 3(2). An individual who holds an office at pleasure may be dismissed without cause, though that individual may be entitled to procedural fairness in the dismissal (Dunsmuir, supra note 1 at paras 91-97).

Emergency Preparedness).

To the relief of many, I am sure. 
In this article, I have attempted to provide an abstract account of how stare decisis may be appropriately applied between courts and administrative decision-makers in a manner that balances the two foundational principles of judicial review. For this theory to become a reality, it must be examined and edited to appropriately apply to the wide range of administrative actors that exist in Canada. It is not a "one-size-fits-all" theory, because one size cannot possibly fit all of Canadian administrative law without distorting the theory or distorting the administrative system. Rather, it is a bird's-eye account of a looming problem in Canadian administrative law. While this article ultimately suggests that a uniquely administrative law approach to vertical stare decisis would be the appropriate resolution to the problem identified by this article, such an approach has not, at this point, been explored or endorsed by Canadian academics or courts. It exists in a purely abstract form. Much work is yet to be done before this stare decisis problem can be solved. 